\title{
SNAPCHAT JAKO INNOWACYJNA APLIKACJA MARKETINGU MOBILNEGO
}

\author{
Grzegorz Szymański \\ Politechnika Łódzka \\ Wydział Organizacji i Zarządzania
}

\begin{abstract}
Streszczenie: Działania marketingu mobilnego współczesnych firm skupiają się na innowacyjnych rozwiązaniach oraz podążają za trendami społecznymi. Aplikacja Snapchat powstała w 2011 roku, a obecnie znajduje się w fazie dynamicznego rozwoju, w Polsce liczba użytkowników przekroczyła już milion osób. Zdecydowanie najbardziej aktywną grupą jest młodzież do osiemnastego roku życia, dla której istotnymi zaletami jest nowa forma rozrywki, brak historii konwersacji oraz atrakcyjne filtry i animacje graficzne. Natomiast najistotniejszą determinantą pierwszego zainteresowania się aplikacją jest fakt użytkowania jej przez znajomych. Marketingowo Snapchat był już wykorzystywany przez światowe marki: McDonald's, MTV, Samsung, Amazon czy National Geographic. Jego istotną cechą jest możliwość przesyłania 10-sekundowych filmów o charakterze reklamowym, które przeważnie ukazują nieoficjalne oblicze firmy, marki, eventu czy życia celebrytów. Szacowania rozwoju aplikacji wskazują ją jako głównego konkurenta, obecnego lidera portali społecznościowych Facebooka.
\end{abstract}

Słowa kluczowe: Snapchat, marketing mobilny, narzędzia marketingu mobilnego

DOI: 10.17512/znpcz.2016.2.14

\section{Wprowadzenie}

Marketing mobilny permanentnie znajduje się w fazie intensywnego wzrostu, zarówno na płaszczyźnie wydatków na reklamę, jak i liczby pojawiających się innowacyjnych form i urządzeń mobilnych. Wzrost popularności potwierdzają także ogólnodostępne badania (Sosnowska 2013), z których wynika, iż 62\% Polaków aktywnie korzysta $z$ Internetu, średnio spędzając przy nim około 15 godzin 40 minut tygodniowo. Zdecydowana większość ludzi młodych (95\%) uważa, iż Internet i komputery są dla nich bardzo ważne, a 53\% z nich jest opinii, że Internet ułatwia im życie oraz pomaga w kontaktach ze znajomymi (Mróz-Gorgoń 2014, s. 958). Klasyczna komunikacja marketingowa staje się współcześnie mało efektywna, dlatego poszukiwane są coraz bardziej innowacyjne rozwiązania. Marketingowcy dostrzegają duży potencjał w komunikacji mobilnej, a aplikacje stanowią jedno z kluczowych zaawansowanych narzędzi. Podążając za trendami oraz popularnością wybranych rozwiązań, podjęto próbę scharakteryzowania zachowań użytkowników Snapchata, jako jednego z dynamicznie rozwijających się rozwiązań współczesnego rynku mobilnego. Aby uszczegółowić cel, sformułowano także hipotezę w postaci: główną przyczyną rozpoczęcia korzystania z aplikacji Snapchat jest używanie jej przez znajomych. 


\section{Marketing mobilny}

Urządzenia mobilne coraz agresywniej wchodzą na polski rynek, zwłaszcza w grupie wiekowej 15-29 lat, gdzie 90\% ankietowanych deklaruje posiadanie smartfona (Jestem3 2015, s. 8). Zgodnie z wynikami badania GfK (Gesellschaft für Konsumforschung) w ostatnim kwartale 2015 roku odnotowano wzrost sprzedaży smartfonów na polskim rynku na poziomie $36 \%$, w odniesieniu do adekwatnego okresu 2014 roku. Wynik ten kreuje Polskę jako jeden z dynamiczniejszych krajów regionu CEE, gdyż w krajach Europy Środkowej i Wschodniej średni wskaźnik wzrostu kształtował się na poziomie zaledwie 4\% (Pasławski 2016). Według raportu Mobirank 83\% użytkowników najpopularniejszego portalu społecznościowego Facebook korzysta $\mathrm{z}$ niego za pomocą smartfona (Mobirank 2015). Internetowe strony firm sektora MŚP coraz częściej posiadają także wersję layoutu dedykowanego pod urządzenia mobilne, czego determinantą jest dynamiczny wzrost udziału ruchu mobilnego w Internecie. A od połowy 2015 roku przyjazność serwisów dla urządzeń mobilnych ma także istotne znaczenie przy pozycjonowaniu SEO (Search Engine Optimization) na urządzeniach przenośnych. Także sektor bankowy dokonuje ekspansji mobilnej, mimo iż na początku XX wieku zdecydowana większość (80\%) prezesów banków deklarowała, że zastosowanie telefonów komórkowych do przeprowadzania operacji finansowych będzie mniej popularne niż dostęp za pomocą komputerów osobistych (Polasik 2002, s. 30). Współcześnie rozwój m-bankingu potwierdza wzrastająca liczba aplikacji mobilnych, a także permanentny wzrost liczby publikacji naukowych dotyczących obszaru bankowości mobilnej (Dewan 2010, s. 367). Przełomowym momentem w obszarze mobilności wydaje się rok 2014, kiedy to po raz pierwszy liczba klientów banków wykorzystujących bankowość mobilną przekroczyła 50\%. Od tego samego okresu odnotowuje się na świecie większą liczbę użytkowników urządzeń mobilnych niż tradycyjnych komputerów osobistych. Także w 2014 roku liczba światowych użytkowników mediów społecznych przekroczyła 2 miliardy, a liczba internautów 3 miliardy, zaś średnia dzienna liczba przesyłanych wiadomości typu IM (Instant Messager) szacowana była na 50 bilionów (Curtis 2014). Natomiast w Polsce pod koniec 2014 roku liczba aktywnych kart SIM osiągnęła wynik 57,6 mln (Grodner 2015, s. 18).

Wraz z eskalacją urządzeń mobilnych oraz atrakcyjnością nowych aplikacji można zauważyć większe zainteresowanie działaniami marketingowymi w obszarze mobilności. Charakterystyka pojęcia marketingu mobilnego wskazuje wykorzystanie mediów mobilnych do przeprowadzania akcji promocyjnych i reklamowych oraz umożliwia przedsiębiorcom dotarcie do coraz większych grup odbiorców (Sadowska 2013, s. 124). W literaturze można spotkać wiele synonimów pojęcia marketingu mobilnego: m-marketing, marketing bezprzewodowy czy określenia angielskojęzyczne mobile marketing, które w niniejszym opracowaniu będą wykorzystywane zamiennie. Definicje pojęcia na przestrzeni lat zmieniały się w zależności od wdrażanych na rynek innowacji w zakresie urządzeń i kanałów marketingowych oraz popularności aplikacji i portali. Pierwsze ujęcia uwzględniały kanał SMS (Marsit i in. 2005, s. 150-157) oraz MMS jako podstawowe media, następnie poszerzono zakres oddziaływania na wszelkie urządzenia mobilne wyko- 
rzystywane w celach promocyjnych i komunikacyjnych (Leppaniemi, Sinisalo, Karjaluoto 2006, s. 37). Współcześnie wskazuje się cztery kluczowe obszary oddziaływania marketingu mobilnego: komunikację, sprzedaż, obsługę klienta oraz badania marketingowe (Frąckiewicz 2015, s. 414). A wśród jego istotnych zalet należy wyróżnić (Konkol 2010, s. 52): wysoki poziom skuteczności, innowacyjność, proste targetowanie odbiorców oraz możliwość personalizacji przekazów. Istotność innowacyjności w rozwoju i sukcesie współczesnego przedsiębiorstwa ma zasadnicze znaczenie (Pomykalski, Blażlak 2010, s. 34-41).

\section{Formy i narzędzia marketingu mobilnego}

Do podstawowych i najczęściej wykorzystywanych narzędzi m-marketingu należą aplikacje mobilne, których determinantą popularności jest wzrost zainteresowania smartfonami. Wśród istniejących narzędzi można wyróżnić:

- SMS (Short Message Service) - reklama SMS należy do typowej strategii „push” charakteryzującej się jednokierunkowym kanałem komunikacji pomiędzy reklamodawcą a odbiorcą przekazu (Barwise, Strong 2002, s. 14-24). SMS jest jednym z pierwszych narzędzi marketingu mobilnego, obecnie jednak coraz mniej wykorzystywanym z uwagi na wzrastającą popularność komunikacji bezpośredniej (IM). Niemniej jednak kluczową zaletą współczesnych kampanii reklamowych SMS jest wysoki współczynnik czytelności, wynikający z przyzwyczajenia odbiorców do odczytywania komunikatów dostarczanych tym kanałem.

- MMS (Multimedia Messaging Service) - multimedialne komunikaty marketingowe wykorzystujące zdjęcia, grafikę, pliki wideo i audio oraz wiadomości tekstowe przesyłane za pomocą urządzeń mobilnych (Gavilan, Avello, Abril 2014, s. 458). Mała liczba przekazów reklamowych MMS, pozwala na wyróżnienie oferty oraz uznawana jest przed odbiorców za nienachlaną formę komunikacji marketingowej.

- Bluetooth - kampanie skupiają się na przekazywaniu treści użytkownikom urządzeń mobilnych wyposażonych w aktywny system Bluetooth. Istnieje możliwość wyboru zasięgu oddziaływania hotspota, jest to zależne od klasy mocy nadawczej, zasięg 100, 10 oraz 1 metra w otwartej przestrzeni. Dopasowanie zasięgu oraz przekazywanych treści powinno być skorelowane z celem kampanii marketingowej oraz miejscem organizowanego eventu. Wśród zalet tej formy komunikacji marketingowej należy wyróżnić: niskie koszty przekazu oraz zakupu lub wypożyczenia hotspota, innowacyjność i ekologiczność.

- NFC (Near Field Communication) - mimo iż najczęściej bezprzewodowa technologia komunikacyjna NFC kojarzona jest $\mathrm{z}$ płatnościami mobilnymi i zbliżeniowymi (Polasik 2014, s. 199), to coraz powszechniej wykorzystywana jest także w marketingu. NFC umożliwia transmisję danych pomiędzy smartfonami a innymi urządzeniami wyposażonymi w chip NFC, przykładowo tablety, telewizory, znaczniki NFC czy terminale płatnicze. Zaletą NFC jest szybkość i prostota działania - nie potrzeba robić zdjęć, pobierać dedykowanych aplikacji czy wyszukiwać w urządzeniu konkretnych danych, wystarczy przy aktywnym NFC zbliżyć telefon do znacznika, aby uruchomić aplikację, przeczytać infor- 
macje czy skonfigurować urządzenie mobilne. Współczesne wyniki prowadzonych kampanii wykorzystujących NFC wskazują na przeciętną ich skuteczność (Gurgul 2012, s. 128-129; Mobext 2015), jednak innowacyjność rozwiązania oraz systematyczny wzrost zainteresowania technologią pozwala na predykcję wzrostu popularności w najbliższym okresie.

- Aplikacje mobilne - tysiące, a nawet miliony aplikacji do pobrania w sieci sprawiają, iż ich wykorzystanie do celów marketingowych stanowi drugoplanowy element strategii mobilnej. Priorytetem jest zachęcenie potencjalnych użytkowników do pobrania oprogramowania. Istnieją dwa kluczowe obszary inspirujące odbiorców do instalowania aplikacji. Pierwszym jest udostępnienie konkretnych korzyści, funkcjonalności, przykładowo w bankowości mobilnej możliwość sprawdzenia stanu konta, dokonanie przelewu czy obsługi płatności zbliżeniowych i mobilnych. Drugą płaszczyzną jest moda, popularność, która poprzez działania marketingu wirusowego zwiększa liczbę użytkowników. Jako przykład wskazać można aplikacje Snapchata oraz WhatsApp.

- E-mail - narzędzie popularne w klasycznej reklamie internetowej, z uwagi na dynamiczny wzrost liczby osób sprawdzających pocztę na telefonie powstają narzędzia wspomagające mailingowe kampanie reklamowe, skierowane wyłącznie do odbiorców mobilnych. Według raportu Litmus 53\% użytkowników sprawdza pocztę poprzez urządzenia mobilne (Jordan 2015), a w ciągu ostatniego roku utrzymuje się wzrostowy trend tej praktyki. Wśród istotnych zasad projektowania mailingu skierowanego do urządzeń mobilnych kluczowe znaczenie ma nadawca oraz preheader, czyli pierwsze zdanie kontentu wiadomości. Mniejszą rolę odgrywa stosowanie jednokolumnowego układu, dużych rozmiarów czcionek, właściwa szerokość kontentu oraz dopasowana grafika.

- Kody QR (Quick Response) - wykorzystywane w marketingu jako narzędzie do przekierowywania odbiorców na wybrane strony internetowe lub przekazywania informacji poprzez dwuwymiarowe matryce zawierające zakodowane treści, zwane także fotokodami. Wadami rozwiązania są stosunkowo niewielka grupa odbiorców oraz skomplikowana forma odczytywania i często konieczność posiadania dostępu do Internetu. Mimo wzrostu liczby smartfontów w Polsce, nie każde urządzenie posiada odpowiednie parametry kamery umożliwiające prawidłowe odczytanie kodu. Działania komunikacji marketingowej stosują fotokody na opakowaniach, plakatach, billboardach, a nawet w social mediach. Determinantą popularności wydaje się być innowacyjność rozwiązania, ciekawość odbiorców oraz wzrost popularności (Watson, McCarthy, Rowley 2013, s. 845).

- Banery mobilne - graficzna forma reklamy na urządzeniach mobilnych, adekwatna do banerów typowo internetowych, jedyne różnice wynikają z przyjętych w standardach wymiarów kreacji reklamowych.

- Strony mobilne - dostosowanie stron WWW do wymogów urządzeń mobilnych jest priorytetem współczesnego świata e-reklamy. Portale niespełniające podstawowych zasad optymalizacji mobilnej są nieużyteczne i pomijane przez większość odbiorców. M-witryna powinna być dostosowana do nawigacji w formie dotykowej, treść i grafika skorelowane $\mathrm{z}$ wizualizacją klasycznej strony, jednak zaprojektowane indywidualnie w oparciu o Responsive Web Design (RWD). 
- IVR (Interactive Voice Response) - telefoniczny interfejs wspomagany automatycznym systemem informatycznym. Podstawowymi cechami systemu jest możliwość automatycznego rozpoznawania osoby dzwoniącej, agregacja danych oraz prezentacja informacji o rozmówcy. Najczęściej wykorzystywany jest $\mathrm{w}$ telemarketingu oraz infoliniach, aby zminimalizować koszty oraz skrócić czas obsługi klienta.

- GPS/AGPS (Assisted / Global Positioning System) - AGPS to specjalizowany rodzaj GPS stosowany zazwyczaj w urządzeniach mobilnych, który wykorzystuje serwery operatora sieci, aby skrócić czas pierwszego znalezienia położenia urządzenia. W Polsce nie dostrzeżono jeszcze potencjału geolokalizacji, niewiele jest firm i kampanii wykorzystujących system GPS, mimo iż w 2012 roku prognozowano dynamikę wzrostu na poziomie 23\% (Jaszkiewicz 2012, s. 12). Ewidentne korzyści wynikające z uwzględniania lokalizacji odbiorcy przekazu w kreowaniu treści reklamowych są potwierdzane w wielu publikacjach (Evans, Moore, Thomas 2012, s. 963; Keikhosrokiani i in. 2011, s. 542-543). Jedną z najprostszych metod jest LBA (Location-based Advertising), czyli reklama wykorzystująca aktualne miejsce położenia użytkownika.

Różnorodność form i narzędzi mobile marketingu pozwala na swobodne dopasowanie do dowolnych celów projektowanych kampanii reklamowych. Zarówno pod kątem personalizacji na podstawie parametrów demograficznych, geolokalizacji, zainteresowań oraz poszukiwanych informacji. Poprzez działania marketingu mobilnego istnieje możliwość nawiązania z odbiorcą trwałych relacji oraz zaangażowania potencjalnego klienta. Innowacyjnym i najbardziej aktywizującym narzędziem wydają się aplikacje mobilne, które udostępniają użytkownikom oczekiwane funkcjonalności lub dostarczają rozrywkę. Liczba istniejących aplikacji jest tak ogromna, że wprowadzenie na ten konkurencyjny rynek nowego rozwiązania, które będzie zauważone i docenione, jest złożonym przedsięwzięciem, zależnym także od wielu zewnętrznych czynników, na które autor ma bardzo niewielki wpływ, jak chwilowa moda.

\section{Determinanty dynamicznego rozwoju Snapchata}

Istota i skuteczność aplikacji w marketingu mobilnym powinna być rozważana w trzech obszarach. Zbudowanie rozrywkowej aplikacji o charakterze reklamowym, gdzie przy jednoczesnym kreowaniu pozytywnego wizerunku marki odbiorca angażuje się poprzez gry i inne formy rozrywki. Kolejnym stosowanym rozwiązaniem jest aplikacja dostarczająca konkretnych korzyści dla odbiorcy. Oprogramowanie stanowi przeważnie wartość dodaną do podstawowych korzyści wynikających z zakupu produktów. Można tutaj wskazać aplikacje bankowe, uczelniane czy też informacyjne rozwiązania organizacji publicznych. Ostatnim zakresem wykorzystania aplikacji mobilnych do działań marketingowych jest opcja wykupu reklamy w popularnych programach. Korzyścią jest niższy koszt jednorazowej emisji, stosunkowo duża liczba odbiorców oraz możliwość targetowania. Niewątpliwie najbardziej ekonomicznym rozwiązaniem jest wykreowanie własne- 
go rozwiązania, a następnie jego spopularyzowanie. Przykładem możliwości dynamicznej dyfuzji aplikacji wśród społeczeństwa informacyjnego jest Snapchat.

Popularność aplikacji mobilnej Snapchat dynamicznie się zwiększa, osiągając w krótkim okresie sto milionów użytkowników. Fenomen popularności, zwłaszcza wśród milenialsów, jest prawdopodobnie wywołany innowacyjnością rozwiązania oraz krótkim okresem istnienia przesyłanych komunikatów, które to czynniki korespondują z koncepcją „Carpe diem”, umożliwiającą młodzieży publikację treści bez zobowiązań i historii. Determinanta braku możliwości wielokrotnego odtwarzania kontenetu wyróżnia tę publikację wśród pozostałych portali i aplikacji społecznościowych. Rozwój Snapchata i jego funkcjonalności wskazuje na duży potencjał marketingowy. Początkowo przesyłane były screeny z krótkim tekstem, obecnie istnieje możliwość tworzenia krótkich filmów, historii w postaci serii zdjęć dostępnych dla odbiorców 24 godziny na dobę oraz powstała zakładka „Discover”, umożliwiająca relację on-line, za obecność w której marki muszą uiścić opłatę.

Wśród znanych marek korzystających z tej nowoczesnej formy marketingu mobilnego są takie korporacje, jak McDonald's, MTV, Samsung, Amazon czy National Geographic. Jednym z pierwszych reklamowych snapów był klip wykreowany przez wytwórnię Universal Pictures pod koniec 2014 roku, promujący horror „Ouija”. Akcja trwała przez dobę, a film został obejrzany przez miliony użytkowników (Izakowski 2015).

Brak konkretnych statystyk udostępnianych przez aplikację powoduje, iż ocena liczby użytkowników oraz przysyłanych snapów szacowana jest na postawie wyników badań oraz rankingów. Serwis Hash.fm udostępnia listę najpopularniejszych kont na Snapchacie, z którego wynika, iż liderzy mają ponad 100 tys. widzów, a wśród 10 najlepszych marek znajduje się Silesia City Center, Coca-Cola, Orange i wiele innych.

Aby zidentyfikować najistotniejsze czynniki wpływające na permanentny wzrost popularności aplikacji Snapchat, przeprowadzono internetowe badanie ankietowe. W badaniu wzięło udział 107 respondentów korzystających z aplikacji Snapchat, zakres czasowy badania to styczeń - luty 2016 roku, wybór narzędzia badawczego w postaci ankiety internetowej został zdeterminowany poprzez czynnik wiarygodnego sposobu dotarcia do badanej populacji, jaką stanowili użytkownicy Snapchata. Link do kwestionariusza umieszczono w mediach społecznościowych: Facebook, Instagram.

W badaniu zastosowano metodę celowego wygodnego doboru próby, która umożliwia szybki dostęp do badanej populacji. Pierwsze pytanie weryfikowało profil wiekowy użytkownika Snapchata. Zakres lat dopasowano do kolejnych etapów szkolnictwa w Polsce, jednak z uwagi na dużą grupę uczniów, która zaczęła naukę w szkołach w wieku 6 lat wyniki nie będą dokładnie odzwierciedlały poszczególnych grup. Najbardziej aktywnymi są gimnazjaliści oraz uczniowie szkół ponadgimnazjalnych, którzy stanowią ponad połowę respondentów korzystających $\mathrm{z}$ aplikacji. Otrzymane wyniki w większości potwierdzają także inne raporty (Berezowski 2015). 


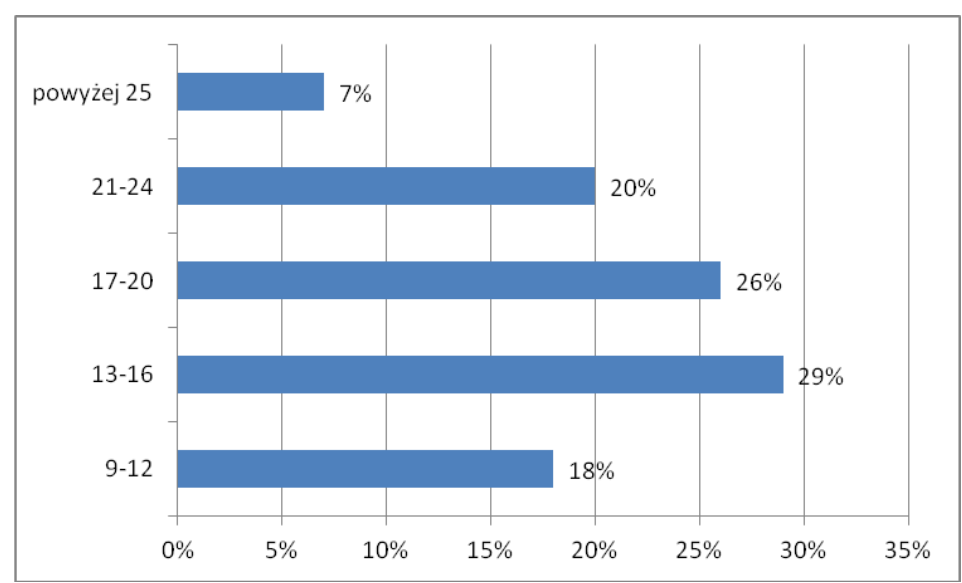

\section{Rysunek 1. Wiek użytkowników Snapchata}

Źródło: Opracowanie własne na podstawie przeprowadzonego badania

Kolejne pytanie identyfikowało częstotliwość korzystania z aplikacji. Uzyskane wyniki wskazują, iż zdecydowana większość respondentów (62\%) codzienne uruchamia Snapchata, prawie co trzeci ankietowany (30\%) 2 do 5 razy tygodniowo, a kilka razy w miesiącu $-8 \%$. Połowa ostatniej grupy to osoby w wieku powyżej 25 lat, co pozwala wnioskować, iż jest to aplikacja atrakcyjna zdecydowanie dla ludzi młodych.

Tabela 1. Częstotliwość korzystania z wybranych funkcjonalności Snapchata

\begin{tabular}{|c|c|c|c|}
\hline $\begin{array}{c}\text { Częstotliwość } \\
\text { korzystania }\end{array}$ & Na żywo & Filtry & Discovery \\
\hline $\begin{array}{c}\text { Zawsze / pra- } \\
\text { wie zawsze }\end{array}$ & $14 \%$ & $31 \%$ & $2 \%$ \\
\hline Często & $34 \%$ & $41 \%$ & $14 \%$ \\
\hline Rzadko & $28 \%$ & $19 \%$ & $37 \%$ \\
\hline $\begin{array}{c}\text { Nigdy / prawie } \\
\text { nigdy }\end{array}$ & $24 \%$ & $9 \%$ & $47 \%$ \\
\hline
\end{tabular}

Źródło: Opracowanie własne na podstawie badania

Tabela 1 przedstawia częstotliwość korzystania użytkowników z dodatkowych funkcjonalności aplikacji. Dodatek „Discovery Stories”, będący komercyjnym zestawem wiadomości reklamowych przekazywanych w formie snapów od parnertów Snapchata, jest najmniej popularnym wśród użytkowników. Główną determinantą małej popularności jest typowo reklamowy charakter przekazów, które wymieniane są na nowe co 24 godziny. Bardziej atrakcyjną opcją (prawie $50 \%$ ogląda zawsze lub często) jest „Live Stories”, gdzie można zobaczyć, snapy różnych osób zebranych na tym samym wydarzeniu. To krótkie filmy przedstawiające konkretny event z różnych perspektyw i miejsc. Jeszcze bardziej popularną funkcją są filtry, 
grafiki i animacje dodawane do zdjęć użytkownika bazujące na geolokalizacji i zazwyczaj korelujące $z$ miejscem przebywania. $Z$ uwagi na ich rozrywkowy charakter $72 \%$ respondentów wskazało, iż korzysta z nich często lub prawie zawsze.

Czas spędzany na Snapchacie był identyfikowany w kolejnym pytaniu ankietowym (Rysunek 2). Większość respondentów (43\%) wskazała, iż dziennie jedynie do 15 minut użytkuje aplikację, natomiast prawie co trzeci ankietowany $(28 \%)$ od 16 do 30 minut, a co czwarty (23\%) do godziny. Otrzymane wyniki ściśle korelują $\mathrm{z}$ danymi z badania Spicy Mobile, gdzie w pasywnym badaniu rynku aplikacji komunikatorów mobilnych aplikacja Snapchat była średnio w ciągu dnia aktywna przez 10 minut i 38 sekund (Wojtas 2015).

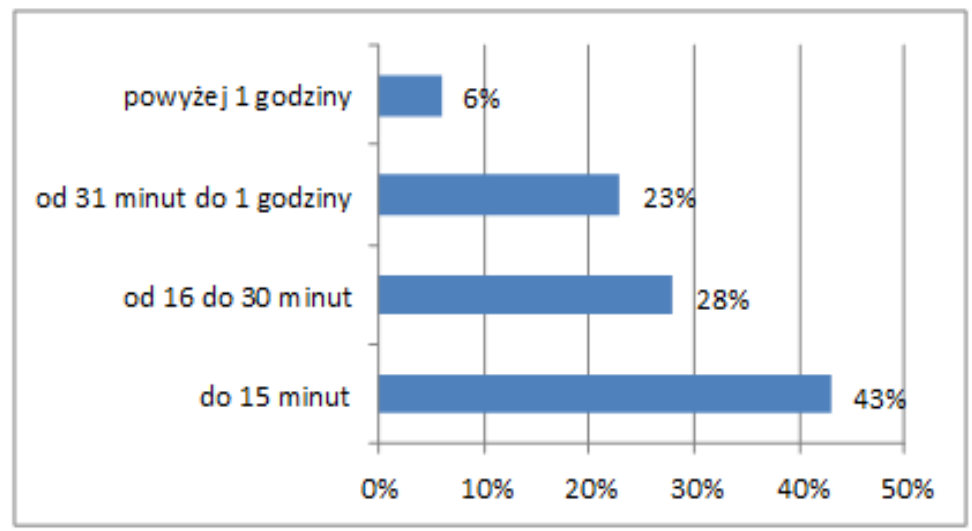

Rysunek 2. Średnia dzienna ilość czasu spędzana na Snapchacie

Źródło: Opracowanie własne na podstawie badania

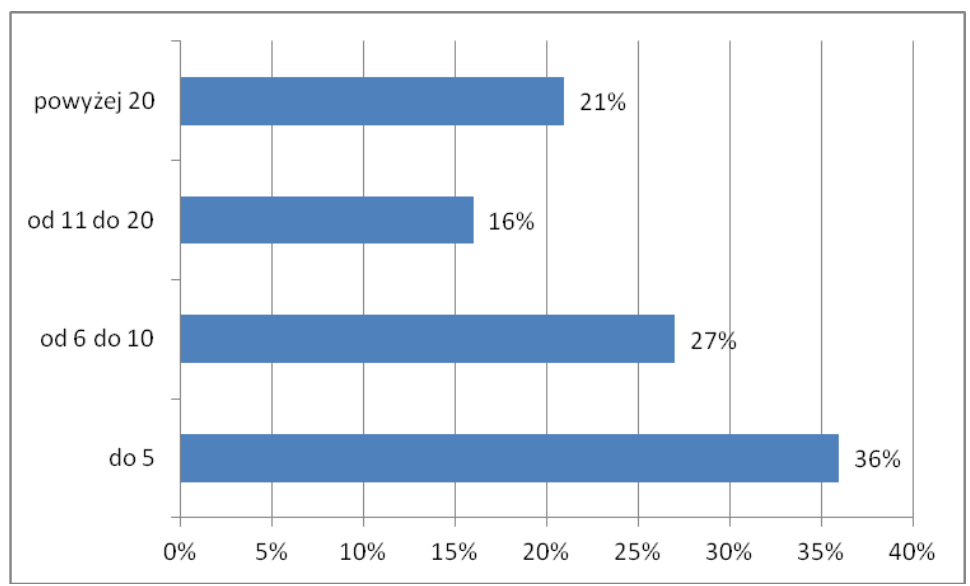

Rysunek 3. Dzienna liczba przesyłanych „snapów”

Źródło: Opracowanie własne na podstawie badania 
Dzienna liczba przesyłanych wiadomości kształtuje się na poziomie 7-8 (Rysunek 3), największa grupa wśród respondentów wskazuje na przesyłanie mniej niż 5 snapów dziennie. Jednak istnieją także użytkownicy przesyłający powyżej 20 wiadomości, co świadczy o dużym ich zaangażowaniu. Kolejne pytania identyfikowały liczbę znajomych w aplikacji oraz liczbę śledzonych celebrytów. Mniej niż 6 znajomych posiada blisko $20 \%$ ankietowanych i są to przeważnie osoby, które wysyłają do 5 snapów dziennie $(90 \%)$ i są w wieku powyżej 25 lat $(80 \%)$. Aby wskazać determinanty niskiej ich aktywności, należałoby przeprowadzić badanie uzupełniające $\mathrm{w}$ dobranej grupie. Od 6 do 10 znajomych posiada $16 \%$, natomiast najbardziej szeroką zbiorowość (46\%) stanowią osoby korespondujące za pomocą aplikacji Snapchat z grupą od 11 do 20 znajomych. Posiadanie powyżej 20 znajomych deklaruje co piąty respondent (18\%), z czego ponad $80 \%$ stanowią osoby w wieku do 18. roku życia.

Wśród młodzieżowych światowych sław, które aktywnie działają na Snapchacie, można znaleźć między innymi: Justina Biebera, Rihannę, Jennifer Lopez, Arianę Grande i wielu innych. Aż 83\% respondentów wskazało, że obserwuje co najmniej kilka kont celebrytów, wyłącznie jednego „śledzi” co dziesiąty respondent, a jedynie $7 \%$ nie jest zainteresowana wydarzeniami z życia współczesnych "fejmów".

Ostatnie pytanie weryfikowało hipotezę postawioną we wstępie, iż najczęstszą przyczyną instalacji aplikacji Snapchat jest fakt korzystania z niej przez znajomych. Jako alternatywne opcje wskazano: ciekawość, reklamę, przypadek, innowacyjność rozwiązania oraz możliwość komunikacji i nietrwałość wiadomości. Ponad połowa respondentów (52\%) jako podstawową inspirację używania aplikacji wskazała właśnie wykorzystywanie jej przez znajomych. Na kolejnym miejscu, z wynikiem $14 \%$, znalazła się odpowiedź „dla zabawy”. Następnie dwa razy rzadziej powodami instalowania aplikacji były ciekawość (8\%), automatyczne usuwanie wiadomości (7\%) i możliwość komunikacji (7\%), a innowacyjność rozwiązania (3\%) oraz reklama (1\%) stanowiły marginalny udział odpowiedzi. Uzyskane wyniki pozwalają zweryfikować pozytywnie postawioną hipotezę. Główną przyczyną rozpoczęcia korzystania z aplikacji Snapchat jest używanie jej przez znajomych.

\section{Podsumowanie}

Popularność marketingu mobilnego systematycznie się zwiększa, czego determinantą jest wzrost liczby urządzeń mobilnych wykorzystywanych do przeglądania kontentu w sieci oraz wzrostu liczby użytkowników portali społecznościowych. Facebook jako lider portali społecznościowych prowadzi w ostatnich latach bardzo kontrowersyjną dla użytkowników politykę prywatności, co mogło być przyczyną dużej dynamiki wzrostu powstałego w 2011 roku Snapchata. Mimo iż główną inspiracją stworzenia aplikacji przez Evana Spiegela była chęć udostępnienia zdjęć wybranym znajomym tylko na chwilę, to współcześnie ta funkcjonalność nie jest kluczowym impulsem wpływającym na rozpoczęcie użytkowania. Przeciętny dzienny czas spędzany na Snapchacie jest znacznie dłuższy od czasu poświęcanego innym popularnym serwisom społeczno- 
ściowym, jak Skype, Instagram czy Twitter, szczególnie wśród osób poniżej 18. roku życia. Młodzież coraz rzadziej ogląda telewizję czy teledyski, teraz media społecznościowe stanowią immanentną część codziennego życia. Snapchat w Polsce ma już ponad milion użytkowników, z czego zdecydowana większość to milenialsi. Snapchat może być bardzo skutecznym narzędziem w marketingu mobilnym, z uwagi nie tylko na dużą popularność, ale także innowacyjną formę przekazu. Odbiorcy, oglądając „Live Stories” oraz snapy znajomych, bardzo często przeżywają chwile oczami innych, poznając ich prywatne życie. Obecnie marketingowy potencjał aplikacji skupia się na funkcjach „Discovery” oraz prowadzenia aktywnego profilu. Fundamentalną cechą jest maksymalny czas przekazu, ograniczony przeważnie do 10 sekund. $Z$ jednej strony jest to bardzo mało czasu na przekazanie konkretnego przesłania reklamowego, jednak u wielu odbiorców następuje zwiększenie koncentracji na spotach trwających tylko 10 sekund. Snapchat jest ogromnie popularny zwłaszcza w USA, gdzie większość eventów relacjonowana jest on-line, na co pozwala także ta aplikacja. W Polsce atrakcyjność marketingowa rozwiązania jest zdecydowanie zauważalna, jednak brak zaufania oraz ewidentnych przykładów potwierdzających skuteczność działań stanowią kluczowe bariery eskalacji mobile marketingu $\mathrm{z}$ wykorzystaniem Snapchata. Niemniej jednak w najbliższej przyszłości aplikacja powinna stać się kluczową formą komunikacji marketingowej $\mathrm{z}$ klientem, zwłaszcza $\mathrm{w}$ grupie młodzieży.

\section{Literatura}

1. Barwise P., Strong C. (2002), Permission-based Mobile Advertising, "Journal Interact Market", Vol. 16(1).

2. Berezowski G. (2015), Demografia użytkowników Snapchata w Polsce, http://napoleoncat. com/blog/demografia -uzytkownikow-snapchata-w-polsce (dostęp: 12.03.2016).

3. CBOS (2014), Internauci 2014, Komunikat z Badań CBOS, nr 82/2014, Fundacja Centrum Badania Opinii Społecznej, Warszawa, http://www.cbos.pl/SPISKOM.POL/2014/ K_082_14.PDF (dostęp: 10.03.2016)

4. Curtis S. (2014), Instant Messaging Overtakes Texting in the UK. The Telegraph Online URL, http://www.telegraph.co.uk/technology/news/10568395/Instant-messaging-overtakestexting-in-the-UK.html (dostęp: 02.03.2016).

5. Evans C., Moore P., Thomas A. (2012), An Intelligent Mobile Advertising System (iMAS): Location-Based Advertising to Individuals and Business, Sixth International Conference on Complex, Intelligent, and Software Intensive Systems, Palermo.

6. Frąckiewicz E. (2015), Rola marketingu mobilnego w rozwoju przedsiębiorstwa, „Studia i Prace Wydziału Nauk Ekonomicznych i Zarządzania”, nr 39, t. 2, Wydawnictwo Naukowe Uniwersytetu Szczecińskiego, Szczecin.

7. Gavilan D., Avello M., Abril C. (2014), The Mediating Role of Mental Imagery in Mobile Advertising, "International Journal of Information Management", Vol. 34, No. 4.

8. Grodner M. (2015), Rynek urządzeń mobilnych w Polsce i na świecie, [w:] Kolenda P. (red.), Perspektywy rozwojowe Mobile Online w Polsce 2015, IAB Polska, http://www.ican.pl/files/book_raport_mobile_2015.pdf(dostęp: 12.03.2016).

9. Gurgul P. (2012), New Mobile Marketing Capabilities of the Android Platform, "AGH Managerial Economics", nr 12, Wydawnictwo AGH, Kraków. 
10. Izakowski Ł. (2015), Raport: Jak globalne marki wykorzystują potencjał Snapchata, http://evigo.pl/10900-jak-globalne-marki-wykorzystuja-potencjal-snapchata (dostęp: 11.03.2016).

11. Jaszkiewicz A. (2012), Perspektywy rozwoju urządzeń mobilnych opartych na wykorzystaniu GPS, [w:] Goliński M., Szafrański M. (red.), Zintegrowany system wspomagania dostępu do informacji w przestrzeni miejskiej z wykorzystaniem GPS i GIS, Wydawnictwo Politechniki Poznańskiej, Poznań.

12. Jestem3 (2015), Polska.jest.mobi, Trzecia edycja raportu „Marketing mobilny w Polsce”, www.tnsglobal.pl/coslychac/files/2015/05/POLSKA_JEST_MOBI_2015.pdf(dostęp: 12.03.2016)

13. Jordan J. (2015), 53\% of Emails Opened on Mobile; Outlook Opens Decrease 33\%, https://litmus.com/blog/53-of-emails-opened-on-mobile-outlook-opens-decrease-33 (dostęp: 10.03.2016).

14. Keikhosrokiani P., Mustaffa N., Sarwar M., Kianpisheh A., Damanhoori F., Zakaria N. (2011), A Study Towards Proposing GPS-Based Mobile Advertisement Service, [w:] Communications in Computer and Information Science, Informatics Engineering and Information Science, E-commerce, ICIEIS 2011, Proceedings, Part II, Kuala Lumpur.

15. Konkol S. (2010), Marketing mobilny, Helion, Gliwice.

16. Leppaniemi M., Sinisalo J., Karjaluoto H. (2006), A Review of Mobile Marketing Research, "International Journal of Mobile Marketing", Vol. 1, No. 1.

17. Marsit N., Hameurlain A., Mammeri Z., Morvan F. (2005), Query Processing in Mobile Environments: A Survey and Open Problems, Proceeding of the First International Conference on Distributed Framework for Multimedia Applications.

18. Mobext (2015), Red Bull jako pierwszy w Polsce wykorzystał NFC w kampanii reklamowej, http://mobext.pl/realizacje/red-bull-nfc (dostęp: 09.03.2016).

19. Mobirank (2015), Mobile w Polsce i na świecie w 2015 roku, https://mobirank.pl/ 2015/01/21/mobile-w-polsce-na-swiecie-w-2015-roku (dostęp: 12.03.2016).

20. Mróz-Gorgoń B. (2014), Markeing Aspects of Using Social Media by Fashion Brands in Poland, [w:] Human Capital without Borders: Knowledge and Learning for Quality of Life Proceedings of the Management, Knowledge and Learning International Conference, ToKnowPress, Portorož 2014, Slovenia.

21. Pasławski K. (2016), Na zachodnich rynkach widać oznaki nasycenia. Sprzedaż smartfonów w Polsce wzrosła o 36 proc., http://www.crn.pl/news/wydarzenia/badania-rynku/2016/03/ sprzedaz-smartfonow-w-polsce-wzrosla-o-36-proc (dostęp: 12.03.2016).

22. Polasik M. (2002), Bankowość internetowa w ocenie prezesów banków, „Bank”, nr 5.

23. Polasik M. (2014), Perspektywy rozwoju mobilnych płatności NFC na rynku polskim, „Annales Universitatis Mariae Curie-Skłodowska. Sectio H, Oeconomia", vol. 48/4, Wydawnictwo UMCS, Lublin.

24. Pomykalski A., Blażlak R. (2010), Istota innowacji w zarządzaniu przedsiębiorstwem, [w:] Bieniok H., Kraśnicka T. (red.), Innowacje w zarządzaniu przedsiębiorstwem oraz instytucjami sektora publicznego. Teoria i praktyka, Wydawnictwo Uniwersytetu Ekonomicznego w Katowicach, Katowice.

25. Sadowska E. (2013), Marketing mobilny a komunikacja marketingowa, [w:] Komunikacja marketingowa współczesne wyzwania i kierunki rozwoju, Uniwersytet Ekonomiczny w Katowicach, Katowice.

26. Saifullah M Dewan (2010), Issues in M-Banking: Challenges and Opportunities, Proceedings of 13th International Conference on Computer and Information Technology (ICCIT 2010) 23-25 December, Dhaka, Bangladesh.

27. Sosnowska J. (2013), Co jest ważniejsze - internet czy telewizja? Najważniejsze wnioski z badania World Internet Project: Polska 2013, http://metro.gazeta.pl/Portfel/ 1,135229,14894700, Co_jest_wazniejsze_internet_czy_telewizja_Najwazniejsze.html (dostęp: 11.03.2016). 
28. Watson C., McCarthy J., Rowley J. (2013), Consumer Attitudes Towards Mobile Marketing in the Smart Phone Era, "International Journal of Information Management", Vol. 33/5.

29. Wojtas T. (2015), Facebook z Messengerem mobilnym liderem społecznościowym w Polsce, Skype przed Instagramem, WhatsAppem i Snapchatem, http://www.wirtualnemedia.pl/ artykul/facebook-Z-messengerem-mobilnym-liderem-spolecznosciowym-w-polsce-skypeprzed-instagramem-whatsappem-i-snapchatem (dostęp: 10.03.2016).

\title{
SNAPCHAT AS INNOVATIVE APPLICATION OF MOBILE MARKETING
}

\begin{abstract}
The actions of mobile marketing companies today are focused on innovative solutions and follow the trends of society. Application snapchat was founded in 2011 and is now at the stage of dynamic development. In Poland, the number of users has already exceeded one million people. The most active group is young people under eighteen years of age, for which the significant advantages is a new form of entertainment, the lack of conversation history and attractive filters and graphic animations. The most important determinant of interest in this application is the fact that her friends use. Snapchat was already used by global brands: McDonald's, MTV, Samsung, Amazon or National Geographic. An important feature is the ability to send 10 -second video of a commercial nature, which usually show the unofficial face of the company, brand, event or life celebrities. Estimating application development indicate it as the main rival to Facebook.
\end{abstract}

Keywords: snapchat, mobile marketing, tools of mobile marketing 